\title{
XI JINPING, “CHINA DREAM", AND CHINESE MILITARY DIPLOMACY TO ASEAN
}

\author{
Lidya Christin Sinaga \\ Center for Political Studies, Indonesian Institute of Sciences \\ J1. Jend. Gatot Subroto 10, Jakarta, Indonesia 12710 \\ lidya.bosua@gmail.com
}

Received: 02 ${ }^{\text {nd }}$ June 2020/ Revised: $08^{\text {th }}$ October 2020/ Accepted: 02 ${ }^{\text {nd }}$ November 2020

How to Cite: Sinaga, L. C. (2020). Xi Jinping, “China Dream”, and Chinese military diplomacy to ASEAN. Journal of ASEAN Studies, 8(2), 173-190. https://doi.org/

$10.21512 /$ jas.v8i2.6483

\begin{abstract}
The rise of Xi Jinping has brought together the idea of the 'China Dream' as a great revival of China. Since the dream referred to the nationalism spirit of a 'century of humiliation, 'it has made national security issues as the core of China's diplomacy. While the national security-related foreign policy has enhanced the military's role in China's foreign policy-making, it brings consequences for China's tougher stance in protecting China's national security. However, Xi Jinping's notion of using military diplomacy has started uneasy relationships between China and some ASEAN countries resulting in 'ongoing negotiation without progress' for the South China Sea dispute. The research examines the impacts of the military's growing role in China's foreign policy under Xi Jinping to its military diplomacy in ASEAN. The results show that Xi Jinping's leadership and vision of the China Dream, which uses military diplomacy as a key tool for advancing its whole diplomatic goals, has been seen as a sign of growing assertiveness.
\end{abstract}

Keywords: Xi Jinping, military, foreign policy-making, national security, military diplomacy, South China Sea, ASEAN

\section{INTRODUCTION}

"Xi's foreign policy assertiveness as part of his unique leadership style highlights crucial PLA role." $(J i, 2014 a)$

The rise of Xi Jinping since 2012 has led to a transformation in China's domestic and foreign policy. Some discussions raised that China's foreign policy under Xi Jinping is more assertive, proactive, and nationalistic than in the previous decades. Some scholars argue that the change is a departure from previous China's peaceful rise. The hallmark of Xi Jinping's 
leadership is the China Dream, which has been established since he first reigned. Xi Jinping refers to the dream as national rejuvenation. The way China pursues its dream, by implication, changes its diplomatic system. While the dream is not specific about the military's revival, however, in the following days, the China Dream was first emphasised on the idea of a strong military. Accordingly, China's foreign policy focuses on national security issues, which, in the end, provides a more influential role for the military to be involved in foreign policy-making. While China's foreign policy is considered assertive under Xi Jinping, the strategy cannot be separated from Xi's domestic interest and relates closely to the development of China's military diplomacy, which has grown since the end of the Cold War.

In light of these observations, the research explores the impacts of the military's growing role in China's foreign policy-making under Xi Jinping to its diplomacy with ASEAN (Association of South-East Asian Nations) countries. While this development relates closely to the development of China's military diplomacy, ASEAN is crucial to be seen as China's military diplomacy puts Southeast Asia as its priority in Asia. Simultaneously, the South China Sea dispute that puts ASEAN and China on the same table is still ongoing and will not end. In light of the observation, the research elaborates on the impacts of Xi Jinping's vision of the 'Strong Army Dream' to ASEAN countries with three critical sections. The essay first sketches out the rise of Xi Jinping and the idea of the Strong Army Dream and how it contributes to the military's role in China's foreign policy-making. Second, the research also substantively assesses the military's more active role in China's foreign policy-making under Xi Jinping. Lastly, the impacts of the military's growing role to China's military diplomacy, especially to ASEAN, will be explained further.

\section{LITERATURE REVIEW}

\section{The Rise of Xi Jinping and the Strong Army Dream}

Xi Jinping was appointed as China's Communist Party Secretary-General in the Eighteenth National Congress on November 15, 2012 ("Remarks on the occasion of meeting", 2012). Since the beginning of his administration, Xi puts a hallmark on his new leadership by revealing the China Dream/Zhongguo Meng. It includes four essential things, namely Strong China (economic, political, diplomatic, scientific, and military), Civilised China (equality and fairness, rich culture, high morals), Harmonious China (friendship between social classes), and Beautiful China (healthy environment and less pollution) (Kuhn, 2013). Xi refers to the dream as the nationalism spirit of China's suffering in the 'century of humiliation' (Miller, 2013) and China's glory under party rule ("Xi Jinping and the Chinese", 2013).

Since then, the idea of the China Dream has been repeated on several occasions, especially at the closing meeting of the National People's Congress on March 17, 2013, the inauguration of Xi Jinping as a president (Xinhua, 2013). Xi pledged to achieve the dream by taking the Chinese way: "spreading the Chinese spirit, which combines the spirit of the nation with patriotism as the core and the spirit of the time with reform and innovation as the core" (Yinan, 2013). Xi Jinping confirmed the China Dream idea as both the 'national revival' and 
China's world power goal. However, this idea is not new as a book entitled "China Dream: The Great Power Thinking and Strategic Positioning of China in the Post-American Age", published in 2010, calling for the awakening of the China's military spirit (Miller, 2013). Another view suggests that Xi's China Dream was a response to Thomas Friedman's column in the Times in 2012 entitled "China Needs Its Own Dream" which expecting "a new Chinese dream that marries people's expectations of prosperity with a more sustainable China" ("Xi Jinping and the Chinese", 2013).

The China Dream has been considered the great revival of China, not only in the domestic sphere but also in its external relations. As argued by Cameron (2013), Xi Jinping's insistence on 'national revival' sends a message that China resumes its place in the world. Both the 'national revival' and China's goal to be a world power are related. As argued by Zicheng, Levine and Liu (2011), "there is a close connection between the rejuvenation of the Chinese nation and China's desire of world power. If China does not become a world power, the rejuvenation of the Chinese nation will be incomplete. Only when it becomes a world power can we say that the total rejuvenation of the Chinese nation has been achieved."

Therefore, in the Central Conference on Work Relating to Foreign Affairs, in November 2014, Xi Jinping proposed to advance multilateral diplomacy aiming to reform the international system and global governance and to increase the representation of China and other developing countries ("The central conference on work", 2014). At this high-level meeting of the China Communist Party (CCP) on foreign relations, $\mathrm{Xi}$ announced a new development in China's foreign policy. He officially laid out his new shift in foreign policy, marking a transformation from Deng Xiaoping's dictum of 'keeping a low profile' to an 'active and creative' strategy.

Xi Jinping has put nationalism, patriotism, and pride at the centre of his leadership (Shi and Tweed, 2014). As argued by Huang (2013), Xi Jinping realised that nationalism is a powerful notion in Chinese society, particularly to secure the support of his nationalist constituency within the military ("Xi Jinping and the Chinese", 2013). Military reform had been on the agenda for China's rejuvenation since the CCP National Congress in 2012. In December 2012, when Xi Jinping inspected naval installations in the Guangzhou Military Region, he stressed a strong military to reach national rejuvenation (Miller, 2013). This emphasis paved the way for the idea of a Strong Army Dream. Besides, robust compliance with the party's orders is also required to be the 'spirit of a strong army' ("Xi Jinping and the Chinese", 2013). Following this, in June 2013, the army confirmed that "the China Dream is the Strong Army Dream, the China Dream leads the Strong Army Dream, and the Strong Army Dream supports the China Dream" ("Xi Jinping - China Dream”, n.d). While it remains to be seen, the Strong Army Dream concept promises to be a guiding force in China's military policy (Miller, 2013).

In 2015, for the first time in Chinese history, China publicly revealed China's Military Strategy White Paper, a change from China's National Defence since 1998. The white paper is essential because it reveals the strategic shift for the People's Liberation Army (PLA). First, it outlines a strategy of 'active defence' and emphasises China's commitment to 'winning informationised local wars' (Kania, 2015). Second, it emphasises the goal of becoming a 
maritime power and a more significant Chinese naval presence farther from the People's Republic's shores (Gady, 2015). There are four main domains for China's force development in the new white paper: cyberspace, outer space, nuclear forces, and finally, the oceans (Chang, 2015). Therefore, in December 2015, the PLA's general command, the PLA Rocket Force, and the PLA Strategic Support Force were officially announced (Liu Hui, 2019).

Xi Jinping's China Dream is not specific about the military's revival. However, a national rejuvenation to regain the level of "prosperity and power enjoyed before the period of national humiliation... [which] requires effective government, a prosperous economy, a harmonious society, and a strong military" (Miller, 2013). However, in the following days, the China Dream was first emphasised on the idea of a 'strong military.' Accordingly, China's foreign policy gives more focus on national security issues in China's foreign policy, which in the end, it provides a more influential role for the military to involve in the foreign policymaking. China established a National Security Commission (NSC), headed by Xi Jinping, Premier Li Keqiang, and the Chairman of National People's Congress, Zhang Dejiang (Zhang, 2015). The new commission seems to solve the problem of fragmentation in China's foreign policy-making. Xi tries to make a breakthrough by putting himself at the centre of new leadership and leaving behind the 'collective leadership' style upheld since Deng Xiaoping (“The power of Xi", 2014).

The rise of Xi Jinping can be considered as a turning point in China's national securityrelated foreign policy. According to Zheng and Liu (2015), national security includes national independence, sovereignty, territorial integrity, people's lives and property, the country's political system, economic development, and social stability. As a result, Xi Jinping's administration is being firm on territorial or sovereignty disputes. As the national securityrelated foreign policy becomes more important, the PLA's role in China's foreign policymaking becomes more influential. The terminology of PLA is unique since it does not necessarily refer to the Chinese army, but the whole armed forces or military. Initially, the PLA consists of the ground forces, naval forces called People's Liberation Army Navy (PLAN), and air forces called People's Liberation Army Air Force (PLAAF). Therefore, Xi Jinping's emphasis on the Strong Army Dream refers to the PLA or military. As Ji (2014a) argued, "the PLA's role in China's foreign policy is integral and deep." Also, Ji (2014b) mentions that the PLA's role in this policy-making is a key in understanding China's diplomacy. The next section highlights the military's more active role in China's foreign policy-making under Xi Jinping.

\section{The Role of Military in China's Foreign Policy under Xi Jinping}

China has dual tracks of decision-making system, the party and the state tracks. The party's track is still higher than the state's (Jakobson and Manuel, 2016). Accordingly, the party is central to China's foreign policy-making. The highest decision-making body, including foreign policy issues, is the Politburo Standing Committee of the CCP (Gore, 2013). As argued by Jakobson and Manuel (2016), "almost all members of the bodies charged with implementing any policies are first and foremost members of the CPC." The elite group of the CCP only consists of seven members who emanate from the 25-member politburo. Consequently, the 
'foreign ministry' of the CCP, the so-called Central International Department (CID), is higher than the Ministry of Foreign Affairs (Gore, 2013).

The role of the Ministry of Foreign Affairs in China's foreign policy-making is not determining, but it shares responsibility with the Central Military Commission/CMC (Ji, 2014a). Since the party's position is more dominant than the state, the role of the Foreign Affairs Ministry in China is weaker than other countries in the world (Jakobson and Manuel, 2016). The Ministry is responsible for foreign affairs in general and government-togovernment relations. However, as argued by Gore (2013), "the main role of the Ministry of Foreign Affairs is the implementation of policies made elsewhere," not even as a coordination body which is still under the party or the so-called the CCP's Central Foreign Affairs Leading Small Groups. Therefore, Gore (2013) depicted the foreign minister's position as "way down the CCP's pecking order."

While the civilians are responsible for daily diplomacy, the security or military-related foreign affairs are the military domain ( $\mathrm{Ji}, 2014 \mathrm{~b})$. The military has an autonomy that can influence foreign policy. The autonomy cannot be separated from its historical relationship with the communist party, particularly in the wartime, when the strength of the CCP primarily depended on the military power (Song, 2008). Therefore, as argued by Jakobson and Manuel (2016), "party leadership upholds a decision-making system that keeps the military at arm's length from political decision making." While the PLA being subordinate to the party, it is ultimately an armed wing of the party, instead of the state, through which the party controls the use of force. Consequently, the government cannot dictate the military since it has a much higher status than the Foreign Affairs Ministry (Gore, 2013). Unsurprisingly, a foreign policy can be conducted without coordination with the Foreign Affairs Ministry.

There are three channels through which the military plays an integral part of China's foreign policy-making: the Central Military Commission (CMC), the Politburo, and the Leading Small Groups/LSGs (Grieger, 2015). The CMC is a high-profile body under the party that aims to control the PLA. The CCP Secretary-General is also the CMC Chairman. Furthermore, as the CMC Chairman, Xi Jinping represents the PLA interests and foreign policy views in the Politburo Standing Committee, since there is no military representative in the inner circle of the Politburo (Grieger, 2015). Finally, there are Leading Small Groups (LSGs) in China's decision-making system that can be channelled as a vehicle for the PLA to feed in the foreign policy process. However, the LSGs are only advisory in nature, with final decisions in the Politburo Standing Committee.

The existence of the LSGs is distinctive for China. These small groups cover any issues from the economics, the 2008 Olympic Games, the 2008 Sichuan earthquake, and foreign affairs. The LSGs play essential roles in supporting the policy-making process. Even it is more important than the ministries (Huang, 2014). However, the LSGs have long played a role in China's power structure since 1958, comprising the most powerful and influential leaders. Xi Jinping is one of the leaders that already involved in the LSGs. In mid-2012, he was a senior leader in the LSGs on maritime security, or the so-called protection of maritime rights (Jakobson and Manuel, 2016). 
When Xi Jinping was appointed as the CCP Secretary-General in 2012, he introduced the new foreign policy team. $\mathrm{Xi}$ is the first member of the Politburo, along with Premier Li Keqiang, Zhang Dejiang, Yu Zhengsheng, Liu Yunshan, Wang Qishan, and Zhang Gaoli. While Li Keqiang was a member of the Standing Committee of the Political Bureau of the Seventeenth Party Central Committee, the remaining people were members of the Political Bureau of the Seventeenth Party Central Committee (china.org.cn, November 16, 2012). While the party's decision-making system is hierarchical, inevitably, $\mathrm{Xi}$ has significant influence in the foreign policy process. Xi then took over by leading the most influential LSGs, such as Taiwan affairs and foreign affairs. Since 'the more powerful the head of LSGs, the more powerful the LSGs are seen to be,' the involvement of Xi in the foreign affairs LSGs makes LSGsthe most potent LSGs (Jakobson and Manuel, 2016).

On the one hand, the establishment of the LSGs is generally accepted as a sign of major political shift. On the other hand, Xi Jinping's decisions to establish and lead two new LSGs (Comprehensive Deepening of Reform and National Security Committee) seem to confirm his strong determination to China's foreign and national security policy. As argued by Huang, Xi is a very different leader from his predecessor, Hu Jintao, as "Xi's style is more like a strongman leader" (Huang, 2013). However, Xi's emphasis on national security affairs cannot be separated from his desire to achieve the China Dream. For the purpose, he will maintain a decisive role of the PLA since it is an essential pillar of the CCP's power.

However, as explained before, foreign policy-making in China is shared between the civilians and the military. In fact, the primacy is still under the civilians (Ji, 2014a). It cannot be separated from the CCP's indoctrination of 'absolute party control' and PLA subordination that manage civil-military relations over foreign affairs. The consensus between the PLA and CCP to prioritise domestic matters and war avoidance has enabled the PLA to deliberately support the civilians' foreign policy at the strategic level. While the civilian-military concern on war avoidance under Xi Jinping remains unchanged, as argued by Ji (2014a), Xi tightens 'proactive stance but a cautious exercise of hard power.' Consequently, China seems to move its defence strategy to war preparation. In April 2016, unsurprisingly, Xi Jinping entitled himself as a commander in chief of the joint battle command centre and, at the same time, urged to build a military command system that was 'capable of winning wars' (Ramzy, 2016).

As the military role in China's national security-related foreign policy is growing, it impacts China's foreign policy. First, the PLA's persuasion and full support for the change have convinced Xi Jinping to conduct a stricter approach to protect China's national security. Ji (2014a) argues that the PLA functionally serves as the foundation and the tool of assertive foreign policy, a job assigned by the party. Since Xi Jinping wants to define his leadership by reasserting and safeguarding maritime territorial disputes, particularly in the South China Sea and East South China Sea, they come as the core interests of China's foreign policy.

Consequently, China had to change its national defensive security strategy from only land defence to land and sea defence (Zheng and Liu, 2015). For a long time, China projected its defence posture in the terrestrially-based strategy. According to Ji (2014a), "the PLA's continental posture of defensive defence matches the civilians' status quo-centred diplomacy 
with land neighbours." Previously, parts of the four general departments were responsible for managing the ground forces. However, now they were integrated into a new PLA's leading organ. The PLA cut the number of its land-based army to less than 50 per cent of the armed forces, with the previous 18 group armies reorganised into 13 new ones (Liu Hui, 2019).

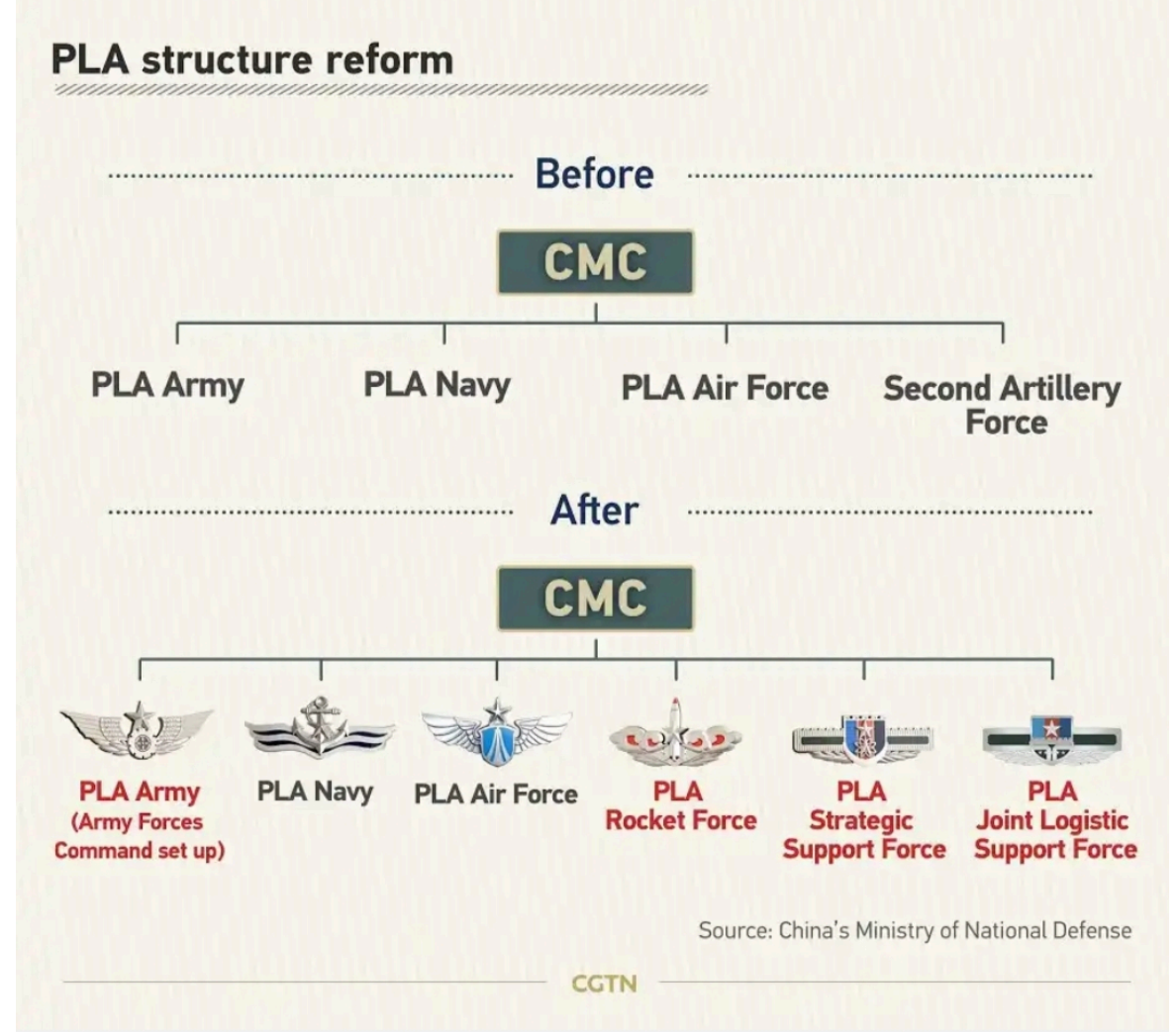

Figure 1. The New Structure of the People's Liberation Army

Source: https://news.cgtn.com/news/2019-12-25/Graphics-Reform-in-China-s-national-defense-and-armedforces-MGRXIeWBZm/index.html

Therefore, since Xi Jinping tries to maintain its national security through maritime territorial disputes, Xi Jinping attempts to increase the Navy's role. As evidenced, Xi Jinping announced the initial idea of a Strong Army Dream in naval installations in the Guangzhou Military Region in 2012. Consequently, the development has made China's foreign policy to be firm to safeguard its maritime rights, while at the same time, it has transformed the PLA Navy into a 'blue water navy' that is actively involved in China's active defence strategy (Poulin, 2016). Whether or not the incident can be seen in the context of the PLA Navy's active defence strategy, it is crucial to consider Chinese naval vessels conducted exercise by crossing Indonesia's sea lane of communication without prior notification in May 2016. The PLA Navy sailed from Hainan Island through the South China Sea, crossed two Indonesian archipelagic sea lanes (Alur Laut Kepulauan Indonesia), the Karimata Strait, the Sunda, and Lombok Straits, the Makassar Strait, the Pacific Ocean near the eastern part of the Philippines and back to Hainan Island (Pattriardjawane, 2016). The PLA Navy violated the UN Convention on the Law of the Sea (UNCLOS) 1982 in which China is a part of this convention, as already 
regulated that "... the requirement of continuous and expeditious transit does not preclude passage through the strait to enter, leave or return from a state bordering the strait, subject to the conditions of entry to that state" (article 38).

Second, the PLA's growing role in national security-related foreign policy-making has made China's security strategy seem to be merely 'tactical military decisions' (Ji, 2014a). As explained before, the civilians and military have shared responsibility in foreign policymaking, between public diplomacy and national security-related foreign affairs. However, as argued by Ji (2014a), in discussing national security issues, "the PLA officers are not less sensible and sensitive towards the crucial questions of war and peace and order of battle." As shown by the case of the Air Defence Identification Zone (ADIZ) Act in 2013, which pushed by the PLA to Xi Jinping, the US has perceived it as China's strategic change. As a result, the US deepened its involvement in the East South China Sea conflict, and ultimately, it changes the security order in the region.

Several factors are contributing to the mismatch between the PLA and civilians. First of all, the growing importance of the PLA in Xi Jinping's administration has made the PLA's officials do not perceive that informing their civilian counterparts about their foreign policy is such an obligation (Ji, 2014a). As argued by Gore (2013), "the military seldom consults diplomats on foreign policy issues, and the latter often hear about the military's action afterward." Consequently, both actors cannot avoid themselves from the problem of lack of coordination, which in the end, the PLA took decisions without approval from the civilians. Furthermore, while the PLA has closer ties with Xi Jinping by the growing importance of national security-related foreign policy, inevitably, the PLA has a larger and more personal influence on Xi Jinping. Towards this end, there is a possibility that China's foreign policy is a matter of different interests between domestic actors, instead of China's vague grand design (Jakobson and Manuel, 2016).

While the PLA has a significant role in shaping and implementing China's foreign policy, the extent to which the idea of the Strong Army Dream impacts China's military diplomacy to its regional partner is crucial to be seen, especially to ASEAN countries. As we know, China's military diplomacy has put Southeast Asia as its priority in Asia (Allen, Saunders, and Chen, 2017).

\section{RESULTS AND DISCUSSIONS}

\section{The Impacts on China's Military Diplomacy: ASEAN Countries in the Core}

At the end of the Cold War, China has acknowledged military diplomacy as a critical component of its overall foreign relations. In a broad sense, China characterised military diplomacy as "external relationships pertaining to military and related affairs between countries and groups of countries, including military personnel exchange, military negotiations, arms control negotiations, military aid, military intelligence cooperation, military technology cooperation, international peacekeeping, military alliance activities, and so on." (Allen, Saunders, and Chen, 2017). China conducts its military diplomacy both in a bilateral 
and multilateral manner. However, as Allen, Saunders, and Chen (2017) argued, most of China's military diplomacy is bilateral, but the PLA now participates in a range of multilateral meetings, conferences, exercises, and competitions. As an instrument of foreign policy, military diplomacy is conducted in a top-down manner and shared between the party and military. While the Central Committee of CCP dictates broad foreign policy goals, the CMC determines specific activities for various PLA parts. This is related to the fact that China's military diplomacy is subject to party and national diplomatic strategy and foreign policy (Cai, 2016).

According to Cai (2016), military diplomacy as an official policy first emerged in the 1998 National Defence White Paper. In this document, it was stated, "China's foreign military contacts are subordinate to and serve the modernization of national defence and the armed forces. China insists on dealing with its foreign military relations independently and engaging in military exchanges and cooperation based on the Five Principles of Peaceful Coexistence. In its contacts with foreign military circles, China has always advocated the principles of mutual respect, enhancing understanding, developing friendship, mutual benefit, and cooperation. China's armed forces have been active in participating in multilateral military diplomatic activities to bring China's armed forces' positive role into full play in the sphere of international military affairs (National Defence Policy, 1998). Since then, almost every two years, China regularly publishes its national defence policy. The exception was in 2012 when China postponed the publication due to internal leadership change.

In 2013, under the new rule of Xi Jinping, China published its national defence policy with the title "The Diversified Employment of China's Armed Forces." This was the first time the National Defence Policy presented in specific issues as such. Then, in 2015, China published a white paper specifically called China's Military Strategy. This is the first white paper systematically expounded on China's military missions and strategic tasks that have never appeared previously in the National Defence Policy. The 2015 China's Military Strategy White Paper stated that:

The traditional mentality that land outweighs sea must be abandoned, and great importance has to be attached to managing the seas and oceans and protecting maritime rights and interests. It is necessary for China to develop a modern maritime military force structure commensurate with its national security and development interests, safeguard its national sovereignty and maritime rights and interests, protect the security of strategic SLOCs and overseas interests, and participate in international maritime cooperation, so as to provide strategic support for building itself into a maritime power (Xinhua, 2015).

The latest was in July 2019 when China issued China's National Defence in the New Era. As stated, this national defence policy aims to sketch in detail the practice, purposes, and significance of China's national defence and its efforts to build a strong military (Erickson, 2019). However, the 2019 National Defence Policy has a different emphasis on the nature of defensive national defence policy. According to Hui (2019), it stated that "China's military role has shifted toward safeguarding China's overseas interest and international peace. China's 
military modernization is primary to safeguard its territory and sovereignty, dismissing the 'China's threat' allegation. The white paper also acknowledged China's need to protect its investment and citizens overseas in the new era" (Erickson, 2019). This focus cannot be separated from Xi Jinping's priority on securing his ambitious project under Belt and Road Initiative.

Institute for National Strategic Studies in 2017 published a report entitled Chinese Military Diplomacy, 2003-2016: Trends and Implications. By focusing on PLA military diplomacy, this report shows that PLA military diplomacy greatly emphasises on Asia (41 per cent). From this percentage, Southeast Asia has the highest priority ( 22 per cent), followed by South Asia ( 9 per cent), Northeast Asia (4.8 per cent), and Central Asia (5 per cent). The indicative is the PLA's strong emphasis on senior-level contact with Europe and countries in Asia, especially in the subregions of Southeast and South Asia. Accordingly, this report also explained that PLA's increasing interactions with Asia cannot be separated from the 2011 US rebalance strategy to Asia and the rise of Xi Jinping to power in 2012. This statement is related to the 2015 China's Military Strategy: "As the world economic and strategic centre of gravity is shifting ever more rapidly to the Asia-Pacific region, the US carries on its 'rebalancing' strategy and enhances its military presence and its military alliances in this region."

However, the more significant portion of China's military diplomacy to Southeast Asia and South Asia is not new. According to Sachar (2004), a large number of military equipment of Pakistan, Bangladesh, Sri Lanka, and Myanmar from China indicate the military diplomacy being pursued by China for balancing India. This was China's attempts in the regional context to minimise India's influence by arming its neighbours and establishing strong military ties with them. As a result, there are strong military relationships and growing dependence of these countries on China. Thailand and Myanmar are two ASEAN countries that have a long story of military diplomacy with China, especially in terms of arms transfer in the mid-1980s (Sachar, 2004). At that time, China was the only source of arms for some states that faced USsponsored sanctions, like Myanmar. Up to now, Thailand still maintains China as its essential source of arms (Storey, 2019). In 2019, Thailand signed a contract with China State Shipbuilding Corporation (CSSC) to build the amphibious vessel for the Royal Thai Navy (“China to build landing", 2019).

Undoubtedly, China's military diplomacy grows with the development of China's foreign policy. Heydarian (2020) figured out three crucial phases of China's foreign policy. The first phase was during the era of Mao Zedong, where China was involved in a protracted ideological war in the 'surrounding environment', especially in Southeast Asia. Local communist movements relied on Beijing's material and political support during the Cold War's early phases. China under Mao rejected the international order as an illegal construction of Western capitalists while openly supporting the revolutionary movement in the 'Third World'. After the Sino-Soviet split in the 1960s, China launched a global struggle against the West (America) and the East (Soviet Union). This era made China face major powers and their regional allies, including Japan and Western-oriented regimes in the Third World. Cai (2016) asserted that China had exercised military exchanges with foreign defence forces in this early period of a new state. 
The second phase was after Mao Zedong's death in 1976 and he was replaced by Deng Xiaoping. Deng made high-level diplomatic visits to key countries in Southeast Asia, such as Singapore, Malaysia, Thailand, and the United States. China then normalises relations with western countries and neighbouring countries, such as Japan and ASEAN member states. Like Mao, Deng still saw China's active participation in global organizations led by the West as a distraction or trap. In other words, Deng only wanted to be involved with the outside world as long as it helped strengthen the country's economic development. Therefore, according to Yasuhiro (2006), China at that time showed a negative response to security cooperation with Southeast Asian countries: "China with its 'horizontal link' tradition prefers bilateral diplomacy with small countries." China just began targeting ASEAN as a whole for dialogue around 1992 to 1993. Yasuhiro (2006) explained, 'horizontal link' tradition dated back to the warring states period of the Chinese dynasty. As described by the Han-era historian Sima Qian, there was a 'vertical link-horizontal link' description. While the former described a policy taken by small countries to ally to oppose the great power, the latter destroyed the 'vertical link' by seeking treaties of alliance one after one. The 'horizontal link' won the war by using divide-and-conquer methods.

The third phase was started by Jiang Zemin, who continued Deng Xiaoping's leadership. In the early 1990s, there was a gradual change as a new form of the authoritarian regime in Beijing, called a 'party-state' collective leadership. This happened after the Tiananmen incident in 1989, which shook the foundation of the communist regime. China's political system dramatically became plural, with the business class gradually entering the higher levels of the Chinese Communist Party (CCP). In this phase, domestic industrialization triggers China to try building relations with other countries, especially for the source of raw materials, both to Africa and Latin America. Besides, this period was also marked by the migration of millions of Chinese citizens.

As a consequence, China began to praise itself as a potential development model for the post-colonial world. China began to see itself as an emerging economic power with global interests. Joshua Ramo (2004) gave the name 'Beijing Consensus' as opposed to the World Bank and the IMF, which are part of the Washington Consensus. The Beijing Consensus is characterised by a non-ideological, selfless, pragmatic approach to global trade and investment. From Jiang Zemin to his successor Hu Jintao, China introduced the third phase of China's foreign policy called the 'charm offensive'. In this period, China was no longer passive and gradually playing a leading role in regional mechanisms (Yasuhiro, 2006). China used the ASEAN Regional Forum (ARF) platform to host several regional meetings. Since 2001, the frequency of defence ministers' attendance increased, including the China-ASEAN Defence Ministers' Meeting (ADMM) and ADMM-Plus (Allen, Saunders, and Chen, 2017). While ADMM is the highest defence consultative and cooperative mechanism in ASEAN, ADMMPlus is a platform for ASEAN and its eight Dialogue Partners, namely Australia, China, India, Japan, New Zealand, Republic of Korea, Russian Federation, and the United States, to strengthen security and defence cooperation for peace, stability, and development in the region (asean.org, n.d). 
However, Cai (2016) underlined that defence diplomacy developed by ADMM-Plus has a conceptual conflict with China's military diplomacy. Although China's military diplomacy is still evolving, China's military diplomacy can be defined as "the pursuit of foreign policy objectives under the guidance of China's national grand strategy through the peaceful employment of military resources and capabilities to maintain national interests (both domestically and overseas), security, and development," meanwhile, defence diplomacy is "a traditional security concept used for the realpolitik purposes of strengthening Western allies against common enemies" (Cai, 2016). The divergence of both concepts lies on, for China's point of view represented by Chinese diplomat Qian Qichen, that "in regard to foreign relations, any armed force to coordinate diplomatic actions cannot be called military diplomacy" (Cai, 2016).

Under Xi Jinping, China's scepticism goes hand in hand with some changes in China's foreign policy. As stated before, China has a greater determination to protect its core interests (Cameron, 2013). The China's core national interests have driven the China's foreign policy, with domestic political stability related to foreign policy. These core national interests include sovereignty, territorial integrity, and sustainable socio-economic development. The report of the 18th CCP Congress of 2012, a guide for the next five years, emphasised the importance of protecting these interests and sovereign rights of China and of not surrendering to outside pressure.

Furthermore, China applies a more proactive and coordinated approach in foreign policy-making (Zhang, 2015). There are two elements of this approach. First, China applies the 'top-level design' in foreign policy-making that has enabled a more centralised foreign policy process and a more efficient foreign policy implementation. For the first time since 1949, China held a Working Conference on Peripheral Diplomacy in October 2013. The conference involved the seven members of the Standing Committee of the Politburo, provincial leaders, leading officials from various central government departments, military, foreign affairs, state security, financial institutions, and key state-owned enterprises. In this conference, $\mathrm{Xi}$ urged all elements to take a more proactive approach in strengthening the relations with China's neighbours. This working conference was held after Xi Jinping announced his vision on Maritime Silk Road (MSR). The revival of MSR is the grand vision of China's foreign policy with its peripheral Eurasian neighbours (Heydarian, 2020). According to Heydarian (2020), while the best way to understand Xi Jinping's BRI vision's strategic logic is to see the geography of Chinese power, its peripheral Eurasian neighbours are the primary key of the overall strategy.

Apart from this, China applies the 'bottom-line thinking', which sets the 'red line' for tolerated actions by other countries (Zhang, 2015). Consequently, China takes a tougher stance in its territorial disputes, especially in the South China Sea and the East China Sea disputes. For Chinese scholars, China's more assertive approach is, in part, the result of Beijing's previously more moderate position. As Heydarian (2020) argued, in the context of the 'charm offensive', we can understand why China signed the Declaration of Code of Conduct (DoC) in 2002. The signing of the DoC during Hu Jintao's time was none other than being influenced by the Chinese leadership at that time with the 'charm offensive' policy. Hu Jintao tried to 
establish good relations with countries in the region and has a new security approach, 'peaceful development'. Not only was the signing of the DoC, but Beijing also made maritime delimitation in the Gulf of Tonkin (2002) with Vietnam, and in 2005 with the Philippines and Vietnam.

Therefore, enhancing the role of the PLA under Xi Jinping, as explained above, undoubtedly gives impacts to ASEAN as the South China Sea dispute is still unresolved. The $18^{\text {th }}$ CCP Congress has reclassified the South China Sea as a national core interest. Simultaneously, there are several indications of China's growing assertiveness in the South China Sea under Xi Jinping. First, China actively conducts military exercises in the South China Sea to strengthen its claims. China regularly sends patrol boats to the area and has even built military posts and airstrips on some islands. These moves heightened regional tensions, especially following China's unilateral declaration of an Air Defence Identification Zone (ADIZ) in the East China Sea. This action raised some worries that China would make a similar declaration regarding the South China Sea (Panda, 2014).

Second, China has carried out extensive land reclamation projects in the South China Sea. However, article 121 of the 1982 UN Convention on the Law of the Sea (UNCLOS) declares that any party cannot claim submerged features (such as shoals) and that "rocks which cannot sustain human habitation or economic life of their own shall have no exclusive economic zone or continental shelf" (United Nations, n.d). China is now building new islands on five different reefs and is creating conditions to sustain human habitation to bolster its claims (Tiezzi, 2014). In January 2014, massive land reclamation was done at Johnson South Reef (Wingfield-Hayes, 2014). Additional land reclamation is also being done on Woody Island, Duncan Island, and Drummon Island, accompanied by infrastructure (Lee, 2015). According to Tiezzi (2014), Johnson South Reef will be the home to a new South China Sea airbase.

Third, Chinese vessels' massive presence in Malaysia's, Vietnam's, and Indonesia's Exclusive Economic Zone (EEZ). Since 2014, China showed its intention to place the Haiyang Shiyou-981 oil rig at a location within Vietnam's EEZ. While this triggered massive antiChinese protests in Hanoi, after nearly two months, on July 16, 2014, the China National Petroleum Corp finally shut down the rig and moved it closer to Hainan Island in southern China. China's presence in Indonesia's EEZ is showed by repeated encroachment to the waters of the Natuna Islands that has been continually resurfaced since 2009. Chinese presence in the Natuna Sea has been continued until December 2019, when Chinese fishing vessels and coast guard ships entered the northern waters of the Natuna Sea. The Indonesian Minister of Foreign Affairs, Retno L.P. Marsudi, on January 3, 2020, issued four points of Indonesia's attitude regarding China's claims in the Natuna Sea, followed by the Indonesian President's Joko Widodo visit to the Natuna Sea. This presence even carried out during the Coronavirus Disease-19 (COVID-19) global pandemic. In April 2020, a Chinese government survey vessel, the Haiyang Dizhi 8, accompanied by a Chinese Coast Guard vessel, entered Malaysia's EEZ and operated close to a drillship under contract to Malaysian state oil company Petronas (Latiff and Ananthalakshmi, 2020). 
Fourth, China shows aggressive actions against other claimants' fishing vessels. In March 2014, China blocked two civilian ships chartered by the Philippines navy to send logistics to the Philippines Marine Unit stationed on Second Thomas Shoal. This disputed shoal in the Spratly Islands is located $200 \mathrm{~km}$ from Kalayaan Islands-Western Philippines and has been claimed as part of the Philippines' continental shelf. In 2016, there are three incidents in March, May, and June between Indonesian patrol vessels and Chinese fishermen vessels fishing in Indonesia's EEZ in the Natuna Islands.

Overall, Xi Jinping's leadership and vision of the China Dream focus on military diplomacy as a key tool for advancing its diplomatic goals. Thus, we can argue that it has created at least two major impacts on ASEAN. First, this development has led to a growing sense of assertiveness, especially in the South China Sea, which is regarded as a national core interest. While growing assertiveness has caused uneasy relationships between China and some ASEAN countries, China's military diplomacy, which has a different approach with ASEAN, has resulted in 'ongoing negotiation without progress' for South China Sea dispute. Second, although China continues to enhance its military diplomacy with neighbouring countries, $\mathrm{Xi}$ Jinping remains essentially unchanged from the 'horizontal link' tradition. China's preference for bilateral diplomacy can be seen as an indicator of a 'great power mentality' that opposes allying since it is regarded as a policy taken by a small country. Meanwhile, 'horizontal link' tradition prefers seeking treaties of alliance one by one with its opponent parties by using divide-and-conquer methods. Therefore, up to now, China deliberately maintains various degrees of bilateral military diplomacy with several ASEAN member states.

\section{CONCLUSIONS}

The growing role of the military in China's foreign policy has been enabled since $\mathrm{Xi}$ Jinping made a strategic shift by emphasizing national security-related foreign affairs. The emphasis on national security cannot be separated from his administration's hallmark: the 'China Dream', which emanates from the nationalism spirit of national rejuvenation. It is a tool for achieving the dream instead of reviving a strong army.

However, the interests of Xi Jinping and the military intertwined with each other. $\mathrm{Xi}$ Jinping needs support for his leadership legitimacy from the military as the central pillar of the CCP's power. Conversely, the military, especially those who were unhappy with their perceived weakness of civilians' foreign policy, seeks to play a more influential role in China's foreign policy-making. While the growing role of military under Xi Jinping is more in domestic interests of both actors, it impacts the whole China's foreign policy. First, the military persuasion and full support for the change have ensured Xi Jinping to conduct a stricter approach to protect China's national security. Second, the growing role of the military in national security-related foreign policy-making has made this policy seem to be merely tactical military decisions. While the assertiveness has become $\mathrm{Xi}$ Jinping's foreign policy identification, he should carefully calculate this growing tendency unless it will only put China in a gravely negative geopolitical situation (Ji, 2014a). 
Overall, Xi Jinping's leadership and vision of the China Dream, which uses military diplomacy as a key tool for advancing its whole diplomatic goals, has been seen as a sign of growing assertiveness. In this regard, the South China Sea dispute is regarded as a national core interest. While growing assertiveness has caused uneasy relationships between China and some ASEAN countries, China's military diplomacy, which has a different approach with ASEAN, has resulted in 'ongoing negotiation without progress' for South China Sea dispute.

\section{REFERENCES}

Allen, K., Saunders, P. C., and Chen, J. (2017). Chinese Military Diplomacy 2003-2016: Trends and Implications. Washington DC: National Defense University Press.

ASEAN. ASEAN Defence Ministers Meeting (ADMM). https://asean.org/asean-politicalsecurity-community/asean-defence-ministers-meeting-admm/

Cai, P. (2016). ASEAN's defence diplomacy and China's military diplomacy. Asia Policy, 22, 89-95. http://dx.doi.org/10.33172/jp.v5i1.487

Cameron, F. (2013, 15 November). China's foreign policy under the new leadership - More continuity than change. Eu-Asia Centre. http://www.euasiacentre.eu/pub details.php?pub $\mathrm{id}=124$

Chang, F. K. (2015, 27 May). Strategic intentions: China's military strategy white paper. Foreign Policy Research Institute. http://www.fpri.org/2015/05/strategic-intentionschinas-military-strategy-white-paper/

China to build landing ship for Thai navy. (2019, 17 September). The Strait Times. https://www.straitstimes.com/asia/se-asia/china-to-build-landing-ship-for-thai-navy

Gady, F. S. (2015, 26 May). China to embrace new 'Active Defense' strategy. The Diplomat. http://thediplomat.com/2015/05/china-to-embrace-new-active-defense-strategy/

Gore, L. L. P. (2013). China's New Foreign Policy Team. East Asian Policy: An International Quarterly, 5(3), 5-17.

Grieger, G. (2015, June). The role of army in China's politics. European Parliamentary Research Service.

http://www.europarl.europa.eu/RegData/etudes/BRIE/2015/564375/EPRS_BRI(2015) 564375 EN.pdf

Heydarian, R. J. (2020). The Indo-Pacific: Trump, China, and the New Struggle for Global Mastery. Singapore: Palgrave Macmilan: Singapore.

Huang, C. (2013). Change Agent or Steady as She Goes? In South China Morning Post. The China Renaissance the Rise of Xi Jinping and the $18^{\text {th }}$ Communist Party Congress. Singapore: World Scientific Publishing. 
Huang, C. (2014, 20 January). How leading small groups help Xi Jinping and other party leaders exert power. South China Morning Post.

http:/www.scmp.com/news/china/article/1409118/how-leading-small-groups-help-xijinping-and-other-party-leaders-exert.

Jakobson, L. and Manuel, R. (2016). How are foreign policy decisions made in China? Asia \& the Pacific Policy Studies, 3(1), 101-110. https://doi.org/10.1002/app5.121

Ji, Y. (2014a). The military role in China's foreign policy-making. East Asian Policy, 16, 1325.

Ji, Y. (2014b). The PLA and diplomacy: Unravelling myths about the military role in foreign policy making. Journal of Contemporary China, 23(86), 236-254.

http://dx.doi.org/10.1080/10670564.2013.832526

Kania, E. (2015, 12 June). China: Active defense in the cyber domain. The Diplomat. https:/thediplomat.com/2015/06/china-active-defense-in-the-cyber-domain/

Kuhn, R. L. (2013, 4 June). Xi Jinping's Chinese dream. New York Times. http:/www.nytimes.com/2013/06/05/opinion/global/xi-jinpings-chinesedream.html?pagewanted $=$ all\& $\mathrm{r}=0$

Latiff, R. and Ananthalakshmi, A. (2020, 23 April). Malaysia calls for peaceful end to months-long South China Sea standoff. The Jakarta Post.

https://www.thejakartapost.com/seasia/2020/04/23/malaysia-calls-for-peaceful-endto-months-long-south-china-sea-standoff.html

Lee, V. R. (2015, 14 April). South China Sea: China is building on the Paracels as well. The Diplomat. http://thediplomat.com/2015/04/south-china-sea-china-is-building-on-theparacels-as-well/

Miller, J. (2013). SITC bulletin analysis: China's Dream army. UC San Diego: Institute on Global Conflict and Cooperation. http://escholarship.org/uc/item/67x812nh

Panda, A. (2014, 27 November). One Year of ADIZ: What Next for China? The Diplomat. http://thediplomat.com/2014/11/one-year-of-adiz-what-next-for-china/

Poulin, A. (2016, 15 April). Going Blue: The Transformation of China's Navy. The Diplomat. http://thediplomat.com/2016/04/going-blue-the-transformation-of-chinasnavy/

Ramzy, A. (2016, 21 April). China’s President, Xi Jinping, Gains a New Title: Commander in Chief. The New York Times. http://www.nytimes.com/2016/04/22/world/asia/chinaxi-jinping-military-commander.html

Remarks on the occasion of meeting with the Chinese and Foreign Press by members of the standing committee of the political bureau of the eighteenth central committee of the 
Communist Party of China. (2012, 15 November).

http:/www.china.org.cn/china/18th cpc congress/2012-11/16/content 27130032.htm

Shi, T. and Tweed, D. (2014, 2 December). Xi Jinping outlines 'Big country diplomacy for China'. Sydney Morning Herald. http://www.smh.com.au/world/xi-jinping-outlinesbig-country-diplomacy-for-china-20141202-11yaj5.html

Song, Z. (2008). The Structural Influence of the Military in China's Foreign Policy Making. Asian Studies Review, 24(1), 71-98. https://doi.org/10.1080/10357820008713260

Storey, I. (2019, 27 May). Thailand's military relations with China: Moving from strength to strength. ISEAS Perspective, 43.

https://www.iseas.edu.sg/images/pdf/ISEAS Perspective 2019 43.pdf

The central conference on work relating to foreign affairs was held in Beijing. (2014, 29

November). Ministry of Foreign Affairs of the People's Republic of China.

http://www.fmprc.gov.cn/mfa eng/zxxx 662805/t1215680.shtml

The power of Xi Jinping. (2014, 18 September). The Economist.

http://www.economist.com/news/china/21618882-cult-personality-growing-aroundchinas-president-what-will-he-do-his-political

Tiezzi, S. (2014, 10 September). Why is China building islands in the South China Sea? The Diplomat. http://thediplomat.com/2014/09/why-is-china-building-islands-in-thesouth-china-sea/

United Nations. (n.d). United Nations Convention on the Law of the Sea. http://www.un.org/depts/los/convention agreements/texts/unclos/unclos e.pdf

Wingfield-Hayes, R. (2014, 9 September). China's island factory. $B B C$. http:/www.bbc.co.uk/news/special/2014/newsspec 8701/index.html

Xi Jinping - China Dream. (n.d). Global Security.

http://www.globalsecurity.org/military/world/china/china-dream.htm

Xi Jinping and the Chinese Dream. (2013, 4 May). The Economist.

http://www.economist.com/news/leaders/21577070-vision-chinas-new-presidentshould-serve-his-people-not-nationalist-state-xi-jinping

Xinhua. (2013, 17 March). President vows to press ahead with "Chinese dream". Xinhua. http://news.xinhuanet.com/english/china/2013-03/17/c 132239786.htm

Xinhua. (2015, 26 May). Full text: China's military strategy. China Daily. http://www.chinadaily.com.cn/china/2015-05/26/content_20820628_4.htm

Yasuhiro, M. (2006, March). An essay on China's military diplomacy: Examination of intentions in foreign strategy. NIDS Security Studies, 8(3), 21-37. 
http://www.nids.mod.go.jp/english/publication/kiyo/pdf/bulletin e2006 2 Matsuda.p $\underline{\mathrm{df}}$

Yinan, Z. (2013, 18 March). China's Dream is Xi’s vision. China Daily. http://www.chinadaily.com.cn/china/2013npc/2013-03/18/content 16315025.htm

Zhang, J. (2015). China's new foreign policy under Xi Jinping: towards 'Peaceful Rise 2.0'? Global Change, Peace \& Security, 27(1), 5-19. https://doi.org/10.1080/14781158.2015.993958

Zheng, S. and Liu, X. (2015, May). The Pursuit of Peaceful Development: How China's Foreign Policy and Its National Security are Connected. Dissertation. Halmstad University.

Zicheng, Y., Levine, S. I. and Liu, G. (2011). Inside China's Grand Strategy. Kentucky: The University Press of Kentucky. 